Krzysztof Obremski*

\section{Tuliusz domowy}

DOI: http://dx.doi.org/10.12775/LC.2017.073

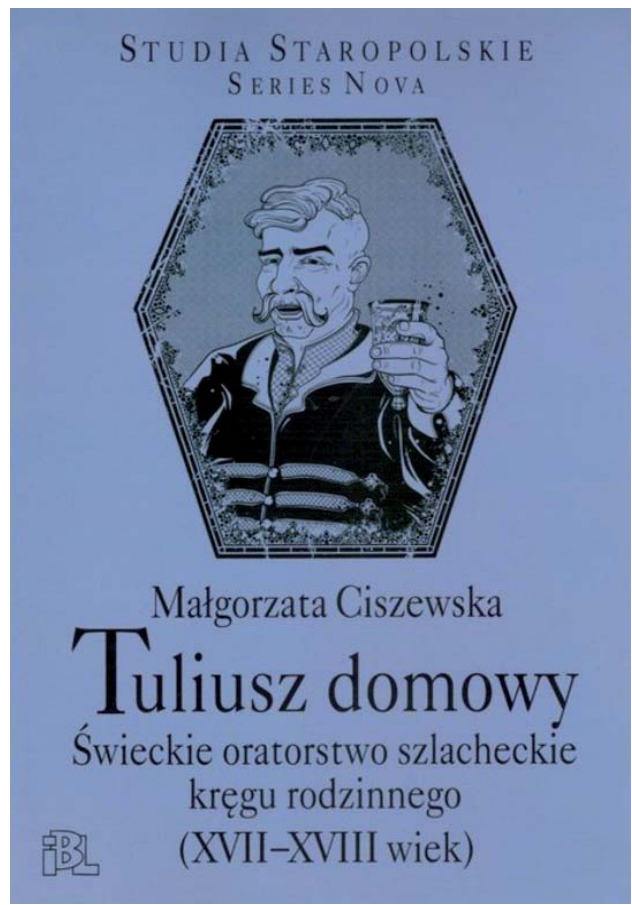

dyby nie podtytuł książki, sam tytuł może pozostałby nawet znikomo zrozumiały. Tuliusz? - Google wyrzuci projekt domu o powierzchni 122, 7 metra. Tuliusz domowy? - domowe są obiady, a więc może to jakieś danie? Dwakroć nie. Słowa Tuliusz domowy sygnalizują swoiste sprzężenie

* Prof. dr hab., kierownik Zakładu Literatury Staropolskiej w Instytucie Literatury Polskiej UMK. Główne zainteresowania badawcze: nurt religijny literatury staropolskiej, sarmatyzm, teoria i praktyka retoryczna, współczesna humanistyka w interpretacji literatury staropolskiej. E-mail: obremski@umk.pl. zwrotne dwóch, poznawczo przepastnych, materii, jakimi były dawna sztuka wymowy i kultura szlachty polskiej.

Trudno dziś sobie wyobrazić humanistyczną kulturę retoryczną z jej czcią dla tego mówcy, który zgodnie pozostawał uważany za nieprzewyższony wzór. Marcus Tullius Cicero był czczony poniekąd może nawet bałwochwalczo. Nad owym kultem jednostki Erazm z Rotterdamu, wszak zwany „księciem humanistów”, nie mógł przejść obojętnie i napisał dzieło opatrzone tytułem Ciceronianius, czyli $O$ najlepszym rodzaju wymowy (pierwodruk 1528 rok). Tamże negatywną postacią był Nosoponus - postać zniewolona ówcześnie „nową chorobą", to znaczy bezgranicznym uwielbieniem Cycerona. „Nie chcę - wyjaśniał Nosoponus - ażeby przylgnęło do mnie jakieś obce, zaczerpnięte $\mathrm{z}$ innego autora wyrażenie i skaziło pełną blasku cycerońską wymowę. Dlatego więc, aby nie grzeszyć nawet nieświadomie, księgi wszystkich innych pisarzy usunąłem sprzed oczu. [...] Nawet we śnie ukazuje mi się tylko Cyceron, nie mam innych widziadel" ${ }^{1}$ (przekład Maria Cytowska). Konsekwencją owego kultu Arpinaty było to, że jakiekolwiek słowo przezeń niepoświadczone powinno zostać odrzucone. Nawet jeśli wyszło spod pióra na przykład Terencjusza.

Cycerońska wymowa nie była jedynie „czystą sztuką”, w Rzeczpospolitej miała bowiem znamienny polityczny wymiar, co najzwięźlej można zwerbalizować i samym tytułem artykułu - Trening oratorski jako sktadnik wychowania obywatelskiego $w$ systemie republikańskim. Przypadek polski - i tym jednym zdaniem: „język

1 Erazm z Rotterdamu, Ciceronianus, sive de optimo genere dicendi (Ciceronianus, czyli O najlepszym rodzaju wymowy). Cyt. za: Źródła wiedzy teoretycznoliterackiej w dawnej Polsce. Średniowiecze - Renesans - Barok, wybór, wstęp, opracowanie M. Cytowska, T. Michałowska, Warszawa 1999, s. 228. 
Cycerona był w Rzeczypospolitej środkiem międzyludzkiej komunikacji dłużej i na szerszą skalę niż w Europie Zachodniej, ale także wypowiadana po polsku interpretacja własnego państwa i obywatelskich wobec niego powinności wzorowana była na formulach zapisanych przez Cycerona, Tacyta, Liwiusza”2. Tak więc „Tuliusz” z tytułu książki Małgorzaty Ciszewskiej to nie postać jedynie familiarna, lecz również ktoś, komu był dawany status - mówiąc przenośnie! - jeszcze rzymskiego „ojca założyciela” szlacheckiej Rzeczpospolitej.

Aby także drugie tytułowe słowo „domowy” - zabrzmiało w jego historycznym kontekście, należy choćby sygnalnie przywołać kulturę polityczną szlachty polskiej. W skardze na wyższe bądź niższe urzędy, traktowane jako (chybiona!) miara szlacheckiej cnoty, napisano: „Urzędnicy, których jest wielkie mnóstwo w każdym województwie, mają pierwszeństwo przed szlachtą inną [niż urzędnicza] z j a k i e g o kolwiek domu pochodzącą" ${ }^{3}$. Tak więc „ród” można utożsamiać z „domem” (stan szlachecki wspóltworzyły rody heraldyczne, to jest rodziny połączone wspólnym herbem). Toteż tytułowe słowo „domowy” należy rozumieć jako „szlachecki” (pierwszy stan feudalnego społeczeństwa przeciwstawiony trzeciemu) oraz „prywatny” (przeciwstawny „publicznemu” czy też „państwowemu”). Znamienny jest dwugłos samych tytułów książek: Krzysztof Koehler, Domek szlachecki $w$ literaturze polskiej epoki klasycznej - Michał Rożek, Etos dworu szlacheckiego. Co w kontekście recenzowanej książki istotne: „Tuliusz domowy” powinien pozostawać przygotowany do uświet-

2 J. Axer, Trening oratorski jako składnik wychowania obywatelskiego $w$ systemie republikańskim. Przypadek polski, [w:] Retoryka antyczna i jej dziedzictwo, red. M. Grzesiowski, Warszawa 1996, s. 135.

3 Cyt. za: A. Zajączkowski, Szlachta polska. Kultura i struktura, Warszawa 1993, s. 45-46. nienia swą krasomówczą sztuką również pospolitych wydarzeń prywatnego życia.

Zapewne najtrafniejszym wprowadzeniem w materię liczącej niemal sześćset stron książki poświęconej sztuce wymowy w kręgu rodzinnym XVII i XVIII wieku będzie autorskie wyjaśnienie Małgorzaty Ciszewskiej, która swój zamiar określiła tymi słowami: „Celem niniejszego studium jest próba rekonstrukcji nie tylko oratorskich modeli najważniejszych obrzędów i ceremonii w domu szlacheckim w XVII i XVIII wieku, ale także odtworzenie krasomówczego aspektu »sarmackiego « modus vivendi w jego sferze prywatnej" (s. 10) ${ }^{4}$. Cudzysłów, jakim zostało opatrzone słowo „sarmacki”, jest tu doprawdy konieczny, gdyż pozwala nie wchodzić $\mathrm{w}$ przepastne zagadnienia determinowane sporami o Sarmację i jej kulturę. Wszak tytuł Palus sarmatica przez Krzysztofa Koehlera został tak wyjaśniony: „Nie pal sarmacki (nie palus, pali), ale raczej moczary, bagno, grzęzawisko (palus, paludis, w sensie: tarda palis, jak w języku Cycerona mawiało się na przykład o nieprzyjemnym wcale Styksie) $[\ldots]^{\prime 5}$. W takim stanie rzeczy najbezpieczniej „sarmatyzm” omijać z daleka i po prostu tego wilka z lasu nie wywoływać.

Jednak jeszcze ważniejsza od „sarmackiego" modus vivendi będzie odpowiedź na pytanie o zakres chronologiczny Tuliusza domowego. Mniejszy problem stanowi przefom XVIII i XIX wieku, chociaż można zapytać o to, w jakim zakresie utrata niepodległości wpływała na tytułowe „świeckie oratorstwo szlacheckie kręgu rodzinnego". Poważniejszy problem wiąże się z przełomem XVI i XVII stulecia - cóż takiego w nim było, że akurat on stał się jedną z granic chronologicznych analizy „najważniej-

\footnotetext{
4 Tak będą lokalizowane cytaty pochodzące $z$ recenzowanej książki.

5 K. Koehler, Palus sarmatica, Warszawa 2016, s. 5.
} 
szych obrzędów i ceremonii w domu szlacheckim w XVII i XVIII wieku"? W książce wyjaśnienia nie znajduję. Z jednej strony w badaniach przeszłości wytyczenie zakresu „od - do” może być postrzegane nawet jako badawcza konieczność, z drugiej strony uzasadnienie przyjętego zakresu badań nie powinno zostać powierzone czytelniczej domyślności. Innymi słowy: Finis Poloniae to zapewne taki fakt historyczny, który mógł nawet znacząco kształtować „świeckie oratorstwo szlacheckie kręgu rodzinnego" (vide uwiecznione Panem Tadeuszem Soplicowo), jednak nawet jeśli przełom XVI i XVII stulecia był przełomem dziejów Rzeczpospolitej, to z jakimkolwiek przełomowym wydarzeniem w dziejach literatury staropolskiej nie jest on wiązany, a zarazem ówczesne przemiany pokoleniowe twórców literatury ${ }^{7}$ na kulturę retoryczną dworków najprawdopodobniej mogły wpływać jedynie w umiarkowanym zakresie.

Rozbudowany spis treści Tuliusza domowego pozwala dostrzec logikę konstrukcji wywodu podzielonego na trzy części: Mówca polski w teatrze życia, Rok staropolski $w \dot{z} y c i u$, tradycji i mowie, Mówki prywatnemu życiu pospolite. Pierwsza część została poświęcona mowom wygłaszanym nad kolebką, podczas wesela, obłóczyn i pogrzebów. Część druga - powinszowaniom determinowanym kolejnymi świętami roku kościelnego. Część trzecia jest mocniej zróżnicowana: od mów powitalnych i pożegnalnych przez toasty i mowy związane z odwiedzinami gości aż po... prośbę o pożyczkę.

Rzecz jednak nie tylko w samej logice konstrukcji wywodu, tę bowiem należy

6 A. Mączak, Przełom stulecia - przełomem losów Rzeczypospolitej, [w:] Przełom wieków XVI i XVII w literaturze i kulturze polskiej, red. B. Otwinowska, J. Pelc, Wrocław 1984.

7 P. Buchwald-Pelcowa, Pokolenia twórców literatury polskiej przełomu XVI i XVII wieku, [w:] Przełom wieków XVI i XVII w literaturze i kulturze polskiej. postrzegać w aspekcie najwyższego nakazu wszystkich literaturoznawców, a szczególnie badaczy literatury staropolskiej. Ad fontes! Sto dwadzieścia rękopisów i pięćdziesiąt siedem starodruków oraz czterdzieści pięć „Innych tekstów źródłowych” to wręcz im ponująca podstawa źródłowa Tuliusza domowego. Toteż w konstatacji „źródłowa klęska urodzaju” (s. 544) nie należy doszukiwać się jakiejkolwiek przesady. Można jedynie dopowiedzieć: w książce Staropolskie oracje weselne. Genologia, obrzęd, źródła (Warszawa 2008) Autorka (jeszcze jako Małgorzata Trębska) spośród ponad 2,5 tysiąca zarejestrowanych przekazów tekstów oracji zacytowała łącznie 277 mów (s. 124).

Należne Autorce Tuliusza domowego słowa podziwu są uzasadnione nie tylko tym, że przedmiotem jej badań stały się przekazy dotąd podejmowane w co najwyżej umiarkowanym zakresie (wszak o ileż prościej poprzestawać na pracy z edycjami tekstów staropolskich). Podobnie ważna rzecz pochwalna wiąże się z tym, że Tuliusz domowy oddaje s t a t u s ł a cin y jako języka i teorii wymowy oraz jej szlacheckiego praktykowania - kultura retoryczna panów braci była dwujęzyczna i to język Cycerona pozostawał jej prymarną postacią, a polszczyzna jedynie ewolucyjnie dochodziła do równorzędnego statusu, by dopiero $\mathrm{z}$ czasem zacząć przeważać.

Jak twierdził Hugo Schuchhardt: „Zrównoważone połączenie mikroskopii i makroskopii tworzy ideał pracy naukowej”. Tak właśnie rzecz ma się w Tuliuszu domowym. $\mathrm{Z}$ jednej strony wnikliwe analizy mikroproblemów retorycznej sztuki słowa panów braci, z drugiej zaś makroproblemy -

8 Cyt. za: E. R. Curtius, Literatura europejska i łacińskie średniowiecze, przekł., oprac. A Borowski, Kraków 1997 , s. 7. 
unaoczniające względność najogólniejszych podziałów.

Granice sfery prywatnej i publicznej w społeczeństwie Rzeczypospolitej XVII i XVIII wieku wydają się dość płynne. Obchody wszystkich świąt i uroczystości związane byly $\mathrm{z}$ domem i zasadniczo mialy charakter rodzinny. Jednak w praktyce imieniny członka rodziny magnackiej mogły przybrać formę celebry publicznej jako świadectwo potęgi rodu, narodziny królewicza zawsze miały rangę państwową, a powitanie monarchy przez marszałka sejmu było aktem publicznym (s. 9).

Podtytuł Świeckie oratorstwo szlacheckie kręgu rodzinnego (XVII-XVIII wiek) może zabrzmieć o tyle zwodniczo, że zdawałoby się wyrazistemu wytyczeniu pola badawczego jednak można przeciwstawić dopełniający go stan wielorakiej osmozy:

Świeckie - jakiekolwiek by nie były relacje między sacrum a profanum (równorzędność, podrzędność czy też zawieranie się profanum w sacrum?), obłóczyny córek panów braci dowodzą tego, jak daleko przenikały się dwie kultury: szlachecka oraz kościelna

oratorstwo - retoryka prymarnie była sztuką żywej mowy (ars bene dicendi - dosłownie: sztuka dobrego mówienia), a przecież od medium pisma niepodobna abstrahować (szczególnie w kontekście sylw oraz epistolografii)

szlacheckie - „Tuliusz domowy” to formuła co prawda szlachecka, jednak sankcjonowana stanowym porządkiem społecznym dyskryminacja mieszczan sama przez się nie rozstrzygała o tym, że ci nie mieli własnej sztuki wymowy

kręgu rodzinnego - rodzina pozostawała częścią rodu (zwanego domem), ten zaś z kolei był częścią całego stanu szlachetnie urodzonych, toteż: „Publiczną rolą potomka jest wspomożenie Ojczyzny (niech rośnie »ad solatium Patriae «), a prywatną - wsparcie rodu na arenie państwowej, co faktycznie również ma charakter publiczny" (s. 40)

(XVII-XVIII wiek) - niepodobna abstrahować ani od wcześniejszego XVI stulecia, ani od późniejszego XIX wieku, kultura szlachecka wszak $\mathrm{z}$ trudem pozwala zamknąć się w jej zasadniczych historycznych granicach: $\mathrm{z}$ jednej strony Mistrz Wincenty i pierwsza wolna elekcja władcy jeszcze w czasach dziś zwanych bajecznymi (Lestek II), z drugiej strony studium Jana Błońskiego Sarmatyzm u Gombrowicza.

W Tuliuszu domowym wnikliwość analiz świeckiej sztuki krasomówczej szlacheckiego kręgu rodzinnego jest uwarunkowana również ówczesną teorią retoryczną, na przykład teoretyk wymowy funeralnej zawczasu wskazywał mówcy wielorakie przyczyny zgonu: truciznę, strzał z broni palnej, cios szabli, przebicie kopią, postrzał z łuku oraz zarazę, utonięcie, spłonięcie, upadek z wysokości, złamanie karku, uderzenie pioruna, a nawet przywalenie głazem (s. 229-230). Mniejsza o to, czy dopowiedzenie na przykład strzał z łuku bądź kuszy byłoby akrybią? Mniejsza też nawet o obżarstwo (ono miało być przyczyną śmierci Michała Korybuta Wiśniowieckiego) czy gangrenę palca nogi (ona zakończyła życie Augusta II Mocnego). Stokroć ważniejsze bowiem to, że teoretycy wymowy kręgu rodzinnego w swoich dziełach nie tylko werbalizowali wielorakie wskazówki, podawali wzory wypowiedzi oraz przytaczali mowy faktycznie wygłoszone, lecz również przewidywali te wszystkie sytuacje życia panów braci, w których ci mocą ówczesnej konwencji społecznej byli niejako zobligowani do krasomówczych wystąpień.

Czytanie Tuliusza domowego to niełatwe wyzwanie, wszak książka jest pokaźna 
(powtórzę: stron niemal sześćset), a zawarta w niej materia dziś może być nawet kulturowo obca - Rzeczpospolita Obojga Narodów dla współczesnych Polaków na ogół pozostaje czymś co najwyżej umiarkowanie znanym. Do lektury zachęcają swoiste perełki, jedynie przykładowo:

- „Miewałaś [dzieci] moja panna, ale wszystko dziurawe, niezupełne; a teraz masz z laski bożej owoc zupełny i z jąderkami” (s. 22) - żartobliwie napisał Jan Sobieski do Marysieńki, która (mając już córki urodzone Janowi Zamojskiemu) właśnie powiła pierwszego syna

- podczas pogrzebu kasztelana krakowskiego i hetmana wielkiego koronnego Józefa Potockiego zostało wygłoszone trzyg o dzin ne kazanie (s. 251)

- podczas innego pogrzebu (1735 rok) w kościele „Lamp samych oliwnych znajdowało się zupełne trzy tysiące, świec i pochodni jarzących białych przeszło czterysta”, więc nic dziwnego, że „dla gorąca nieznośnego ciężko było w kościele wysiedzieć” (s. 266)

Recenzent powinien starać się, aby oddzielać to, co dyskusyjne, od tego, co błędne (przynajmniej w jego przekonaniu). To, co dyskusyjne $\mathrm{w}$ Tuliuszu domowym, można wypunktować następującym wyliczeniem:

- pierwsza wątpliwość wiąże się z tytułowym „Tuliuszem” - jakakolwiek by nie była staropolska pisownia
(Tullius, Tullianus czy Tulijusz), przyjęta w książce forma „Tuliusz” wydaje się najdalsza od źródlowej pisowni

- już w spisie treści znajduję zdrobnienie: Mówki prywatnemu życiu pospolite - toż deminutivum nie wydaje się szczęśliwe, trafniejsze byłyby obecne w książce „oratiunkule” (s. 469)

- klasyczna teoria retoryczna wyróżniała trzy rodzaje (sądowy, doradczy, pokazowy), byłby jednak wyróżniany jeszcze $\mathrm{czw}$ a r ty ro$\mathrm{d} \mathrm{z} \mathrm{a} \mathrm{j-okolicznościowy} \mathrm{(s.} \mathrm{507)?}$

$\mathrm{Z}$ kolei tego, co w Tuliuszu domowym byłoby błędne (przynajmniej w moim przekonaniu), nie znajduję. Zarazem nie skrywam, że ilustracja na pierwszej stronie okładki po prostu nie podoba mi się, jednak De gustibus non est disputandum.

Tuliusz domowy to zarazem zwien czenie badań nad tą sztuką wymowy, która była wytyczana trzema tytułowymi słowami (świeckie - szlacheckie - rodzinne) oraz sekularną periodyzacją (XVIIXVIII wiek), jak też zarazem w s k a z a n i e nowych kierunków dalszych badań, wśród nich może nawet na plan pierwszy wysuwają się analizy porównawcze (szczególnie i tylko najogólniej: retoryka a poezja; konkretniej i jedynie przykładowo: dworkowe toasty imieninowe a Wiersze imieninowe poetów $z$ drugiej połowy XVIII wieku ${ }^{9}$ ), komparatystyczne (Rzeczpospolita Obojga Narodów a inne państwa Europy) oraz wymowa religijna (na przykład co prawda panowie bracia do klauzury żeńskich klasztorów wejść nie mogli, ale tamże wkraczała
9 Wiersze imieninowe poetów $z$ drugiej połowy XVIII wieku, wstęp, wybór, oprac. B. Wolska, B. Mazurkowa, T. Chachulski, Warszawa 2011. Por. K. Orszulak-Dudkowska, Polska tradycja imieninowa a tradycja szlachecka, [w:] Tradycje szlacheckie we współczesnej kulturze polskiej, red. M. Lutomierski, Toruń 2014. 
szlachecka wymowa, czego wyraziście dowodzą mowy ksieni grodzieńskich brygidek Teresy Chreptowiczówny ${ }^{10}$ ).

Nowe wyzwania będą zawierać się nie tylko $\mathrm{w}$ poszerzaniu i pogłębianiu zagadnień już dotąd podejmowanych, mogą bowiem wiązać się również z tym, co za sprawą wciąż niedocieczonej interpunkcji staropolskiej pozostaje czymś, co najłatwiej określić słowami ignotum per ignotum. Mam tu na myśli rytm prozy retorycznej - poprzestańmy na przykładzie jednego zdania (pochodzącego z wzorcowego powinszowania Bożego Narodzenia):

Niech się kwilącego łzy Boga $<w>$ jak najdłuższe przemienily wesela; niech pieluszki wszytkie natarczywe nieszczęścia pokrępują; niech pasterska muzyka przypadki i nieszczęścia wszytkie wytrąbi; niech dzień pierwszy życia w ciele przedwiecznego Słowa niezrachowanych lat użyczy (s. 301).

Rzecz nawet nie tyle w samych liczbach sylab współtworzących poszczególne zdania składowe $(21+17+19+23)$, ile $\mathrm{w}$ paralelizmach (czterokrotnie inicjalne „niech” oraz orzeczenia u końca paralelnych członów). Również jakże krótkiemu zdaniu Krzysztofa Zawiszy - „Weseliśmy byli, pili i tańcowali; nazajutrz cały dzień leżałem słaby będąc" (s. 359) - niepodobna odmówić tego, co w teorii literatury jest określane jako uprządkowanie naddane, tu mierzone również liczbami sylab poszczególnych zdań składowych: $6+7 ; 13$.

Rytm tak świeckiej, jak też kościelnej prozy retorycznej to badawczy nakaz dyktowany przez samego autora Retoryki:

10 Por. Dzieje kapitularne zakonnic świętej matki Brygitty konwentu grodzieńskiego, opr. M. Borkowska OSB, K. Obremski, Toruń 2001.
Tekst prozy nie powinien mieć formy metrycznej wiersza, ani też nie powinien być pozbawiony rytmu. $[\ldots]$ Granice wszystkim rzeczom wyznacza przecież liczba, a tą liczbą dla formy językowej jest właśnie rytm, podczas gdy miary wierszowe są tylko jego odcinkami. Dlatego proza musi posiadać rytm, nie może natomiast posiadać miar wierszowych, bo zamieni się w poezję. Nie wolno jednak stosować rytmu rygorystycznie, lecz tylko w ograniczonym stopniu $^{11}$.

W większym bądź mniejszym zakresie tak właśnie można czytać wszystkie cytowane w Tuliuszu domowym fragmenty źródłowych wypowiedzi (zarówno łacińskie, jak i polskie). Jednak zarazem dotąd wręcz niepokonaną barierą badań rytmu prozy retorycznej pozostaje problem stanowiony staropolską interpunkcją - determinowaną ówczesną żywą mową, nie zaś (jak współcześnie) głównie składnią wypowiedzi oraz jej logiką. Pośrednim i zarazem jakże wymownym unaocznieniem ogromu zawiłości poznawczego wyzwania stanowionego zrytmizowaniem prozy retorycznej niech będzie moje wspomnienie $\mathrm{z}$ pewnej konferencji („Potrzeby i programy akademickiego kształcenia edytorów"; 28-31 maja 1998 roku; Zakopane). Otóż podczas dyskusji Profesor Zbigniew Goliński o (wówczas już nieżyjącym!) Profesorze Konradzie Górskim i jego (najogólniej!) pozytywnej postawie wobec staropolskiej interpunkcji ${ }^{12}$ powiedział: „Górski zwariował”. Tak więc

11 Arystoteles, Retoryka, [w:] idem, Retoryka. Poetyka, przekł. H. Podbielski, Warszawa 1988, s. 254 -255 .

12 „[...] dla poznania autentycznego dźwiękowego kształtu tekstów poetyckich i prozy artystycznej aż do romantyzmu włącznie winniśmy uszanować wolę autorów, piszących przed radykalną zmianą, jaka nastąpiła w polskiej interpunkcji w ciągu w. XIX, i wydawać ich dzieła z zachowaniem dawnych zwyczajów przestankowania". K. Górski, Zagadnienie interpunkcji w wydaniach klasyków polskich, w: idem, Rozważania teoretyczne. Literatura. Muzyka. Teatr, Lublin 1984, s. 263. 
De mortuis nil nisi bene - jednak wyłączywszy staropolską prozę retoryczną z jej interpunkcją postrzeganą niczym klucz do artyzmu prozaicznej sztuki słowa.

W traktacie O poezji doskonatej Maciej

Kazimierz Sarbiewski Polaków scharakteryzowal tymi słowami:

Ale jak lubią długo o wszystkim mówić, tak też powoli zabierają się do czynu. [...] Oni jedni korzystają z dwu najpiękniejszych skarbów, jakie tylko może posiadać państwo: z wolności i wymowy, która jest identyczna ze swobodą słowa. Oni jedni wybierają sobie króla, swobodnie żyją i wypowiadają się pod jego rządami. Gdzie indziej wymowa znajduje schronienie w książkach, u nas panuje na zebraniach, w sądach, na sejmach. Dlatego to jak Hiszpan jest $\mathrm{z}$ natury teologiem, Włoch filozofem, Francuz poetą, Niemiec historykiem, tak Polak mówcą. Zbytnie jednak zamiłowanie i skłonność do krasomówstwa prowadzi ich często do dziecinnej niemal gadatliwości ${ }^{13}$.

Owe słowa „Horacego chrześcijańskiego" studium Tuliusz domowy pozwala głębiej rozumieć, jednak choćby w przybliżeniu nie wskazuje ono granicy, na której kończy się (niejako sprzężona z wolnością polityczną polskiej szlachty) zacna wymowa, a zaczyna niecna wielomówność. Jeszcze współcześnie owa granica nie jest bynajmniej problemem akademickim $\mathrm{w}$ pejoratywnym tego słowa znaczeniu...

Małgorzata Ciszewska, Tuliusz domowy. Świeckie oratorstwo szlacheckie kręgu rodzinnego (XVII-XVIII wiek), Instytut Badań Literackich PAN, Warszawa 2016, ss. 581.

13 M. K. Sarbiewski, O poezji doskonałej, czyli Wergiliusz i Homer, przekł. M. Plezia, oprac. S. Skimina, Wrocław 1954, s. 100. 